\title{
A fotografia e seus tentáculos: interpretações possíveis no universo dos arquivos
}

\author{
Photography and its tentacles: possible interpretations in the universe files
}

\author{
André Malverdes \\ Doutor em Ciência da Informação pela Universidade de Brasília - UnB. \\ Professor titular do Departamento de Arquivologia, Universidade Federal do Espírito Santo - UFES. \\ E-mail: malverdes@gmail.com \\ André Porto Ancona Lopez \\ Doutor em História Social pela Universidade de São Paulo - USP. \\ Professor da Faculdade de Ciência de Informação, Universidade Federal de Brasília - UnB. \\ E-mail: apalopez@gmail.com
}

\begin{abstract}
Resumo
A fotografia não somente constitui um tipo de representação icônica que goza de um extenso uso cultural e uma ampla trajetória histórica como também apresenta uma morfologia específica e um tipo documental com características específicas. Ao longo das duas últimas décadas, surgiu um grande interesse no âmbito das ciências sociais e humanas em torno da fotografia com uma abordagem e enfoques interdisciplinares. Nosso trabalho pretende enfocar a fotografia na perspectiva informativo-documental, examinando a imagem como evidência de um registro dentro de um sistema da informação, estudando a gestão dos fundos e coleções fotográficas, e do tratamento de seu conteúdo de representação icônica para gerar representações documentais secundárias, visando possibilitar a recuperação dos documentos e das informações neles contidas. Partindo dessa perspectiva, buscaremos a partir de agora a contribuição de autores como Agustín Lacruz (2015), Salvador Benítez e Ruiz Rodriguez (2006), Boadas I Raset; Casellas; Suquet (2001), Valle Gastaminza (1999), Lacerda (2008) e Lopez (2000), que irão corroborar na construção teórica de nosso artigo, no que diz respeito aos conceitos da fotografia e de suas características. Buscamos, neste breve artigo, elencar a problemática da fotografia dentro do âmbito do arquivo e conceituar os documentos fotográficos dentro de um estado de coisas. Uma vez reconhecida a fotografia como documento de arquivo, são necessários estudos e reflexões sobre as atividades de arquivo como a avaliação, a classificação e a descrição arquivística e a aplicabilidade destas na fotografia como objeto de análise documental, seus métodos e possibilidades de leitura de imagens.
\end{abstract}

Palavras chaves: Documento fotográfico. Documento de arquivo. Imagem. Fotografia.

\begin{abstract}
The photograph is not only a kind of iconic representation which enjoys an extensive cultural use and a wide historical background but also presents a specific morphology and a documentary type with specific characteristics. Over the past two decades, there was a great interest in the social sciences and humanities around the picture with an interdisciplinary approach and historiographical approaches, the history of photographic techniques, philosophical, artistic, anthropological, sociological, psychological, semiotic, educational, to name just a few here. Our research intends to focus on photography in the informative-documentary perspective, examining the image as evidence of a record within an information system by studying the management of funds and photographic collections, and treatment of their iconic representation of content to generate secondary documentary representations, aimed at enabling the recovery of the documents and the information contained therein. From this perspective, we seek from now on the contribution of authors as Agustín Lacruz (2015); Benitez and Rodrigues (2006), Boadas I Raset; Casellas; Suquet (2001), Valle Gastaminza (1999) Lacerda (2008) and Lopez (2000), which will corroborate the theoretical construction of our research, with regard to the concepts of photography and characteristics. We seek in this brief presentation elencarmos the picture of the problem within the scope of the file and conceptualize the photographic documents within a state of affairs. Once recognized photography as archival document is necessary studies and reflections on file activity such as evaluation, classification and archival description and its applicability in photography as documentary analysis object, its methods and $\mathrm{p}$ ossibilities in the main reading methods images.
\end{abstract}

Keywords: Photographic paper. Archival document. Image. Photography. 


\section{Introdução}

A primeira fotografia se atribui ao francês Joseph-Nicéphore, realizada mediante a exposição à luz de uma placa metálica recoberta de pó de asfalto e óleo de lavanda quente. Louis-Jacques-Mandé Daguerre revelou placas de cobre com vapores de mercúrio em 1837 e conseguiu fixar as fotos com uma solução de sal comum e, em 19 de agosto de 1839, François Arago apresentou oficialmente o daguerreotipo na Academia de Ciências de Paris. Na metade do século XIX, surgiu a fotografia, e a partir daí começou-se a fixar, num meio físico, as primeiras imagens reproduzidas mecanicamente, com o auxílio de equipamentos ópticos e produtos químicos.

Nos primeiro anos em que, na França, Daguerre trabalhou para aperfeiçoar seu descobrimento, na Inglaterra, Willian Henry Fox Talbot (1800-1877) utilizava a câmera escura em suas composições de pintor amador1. A partir de 1833, experimentou a fixação de imagens sobre papéis impregnados de nitrato de prata, aos quais denominou "desenhos fotogênicos". A partir de 1839, no trabalho de conhecer os descobrimentos de Daguerre, Talbot comunica à Royal Society de Londres e à Academia de Ciência de Paris os resultados que havia obtido e denomina pela primeira vez, por conselho de seu amigo John Herschel (1792-1871), suas imagens de fotografia (BOADAS I RASET; CASELLAS; SUQUET, 2001, p.19).

Talvez nenhuma outra invenção da humanidade tenha capturado a imaginação do público e conquistado o mundo com tanta rapidez como aconteceu com o daguerreótipo. $\mathrm{O}$ Manual de Daguerre, publicado por ordem do governo francês, foi impresso em nada menos do que trinta e duas edições, em oito idiomas, durante 1839 e 1840. Inicialmente, as sessões de pose transcorriam em condições muito difíceis, já que era necessário que o fotografado permanecesse imóvel entre 15 e 20 minutos de cara para a luz solar para se obter bons resultados. Mais experimentações se seguiram e, em pouco mais de dois anos, melhorias química e óptica resultaram em um aumento da sensibilidade das placas do daguerreótipo, menor tempo de exposição, câmeras menores e lentes melhoradas. (SCHWARTZ, 2000, p. 4).

Evidentemente, nos primeiros momentos, tirar fotos demandava um aparato caro e complicado, distante da era das cômodas câmeras de bolso que convidam qualquer um a tirar fotos. “As primeiras câmeras, feitas na França e na Inglaterra no início da década de 1840, só

${ }_{1}$ Embora esse seja um debate recorrente não temos como objetivo desta pesquisa discutir se a fotografia se define como técnica ou como arte. 
contavam com os inventores e os aficionados para operá-las" (SONTAG, 2004, p. 18). Inicialmente, a prática de fotografar era reservada ao passatempo dos ricos e obsessivos, e tirar foto não tinha nenhuma utilidade social clara. Somente com a industrialização foi possível o uso social para atividades de fotógrafos e a popularização da fotografia nas mais diversas camadas sociais.

Claro que o papel de testemunho ocular da fotografia sempre foi inquestionável, diante das mais diversas funções incorporadas pela técnica de registro das imagens. Sontag (2004, p. 32) destaca que com a industrialização da fotografia aconteceu uma rápida absorção pelos meios burocráticos de gerir a sociedade.

[...]. As fotos foram arroladas a serviço de importantes instituições de controle, em especial a família e a polícia, como objetos simbólicos e como fonte de informação. Assim, na catalogação burocrática do mundo, muitos documentos importantes não são válidos a menos que tenham, coladas a eles, uma foto comprobatória do rosto do cidadão.

\section{Um breve panorama do uso da fotografia na sociedade}

A família estabeleceu uma relação íntima com a fotografia quase desde que esta apareceu, e depois que George Eastman inventou a Kodak, em 1888, esse meio se tornou o instrumento principal de sua representação. A revolução industrial, que produziu tecnologia fotográfica, foi acompanhada por uma revolução do consumidor, tendo como alvo principal as famílias, que passaram a comprar fotografia e câmeras.

En 1899 George Eastman empezó a comercializar sus productos Kodak bajo el lema
"you press the bottom, we do the rest" ("apriete el botón, nosotros nos ocupamos del
resto"), con la intención de empezar a captar grandes cantidades de clientes que, sin
tener conocimientos técnicos, compraran material fotográfico. Desde entonces, la
obtención de retratos dejó de ser patrimonio de profesionales o de un sector elitista de
aficionados. Con la masificación del mercado fotográfico, el encargo de retratos a los
fotógrafos profesionales se fue reduciendo a las ocasiones especiales, relacionadas
generalmente con ceremonias religiosas (p.e. bautizos, bodas, comuniones, etc.).
(BOADAS I RASET; CASELLAS; SUQUET, 2001, p. 138).

No processo de inserção da fotografia na vida do individuo, em alguns contextos, era comum a própria burocratização e seu uso nos processos de controle servirem para democratização da fotografia na vida dos trabalhadores e dos menos afortunados economicamente. Um exemplo é o arquivo de Assis Horta, fotógrafo mineiro, que tinha um estúdio em Diamantina e fez o registro fotográfico de várias famílias ao longo de sua trajetória no trabalho de fotógrafo. 
Com a Consolidação das Leis do Trabalho (CLT), instituída pelo presidente Getúlio Vargas, em $1^{\circ}$ de maio de 1943, e que instituiu um novo documento, a Carteira de Trabalho e Previdência Social, milhares de pessoas que nunca haviam sido fotografadas tiveram pela primeira vez o seu próprio retrato. Após essa obrigatoriedade da fotografia em documento, muitos cidadãos em Diamantina procuraram o estúdio de Assis Horta com o intuito de obter esse tipo de foto. Alguns desses eram operários que, como dissemos, obtinham seu primeiro retrato. A magia provocada pela experiência da imortalidade através da fotografia fez com que muitos procurassem o fotógrafo após a sessão para que ele tirasse retratos de sua família. (CAZES, 2013, p. 6).

Para Leite (2001, p. 159), os retratos de família estão fundamentalmente ligados aos ritos de passagem que marcam uma mudança de situação ou troca de categoria social, como aniversários, batizados, festas de fim de ano, casamentos, enterros etc. Segundo a autora, há dois tipos diferentes de retratos de família: os formais, que abrangem os retratos de casamento, batizados, formaturas, comunhões, e os informais que compreendem os retratos de férias e de momentos ociosos.

Para Sontag (2004, p. 19), comemorar as conquistas de indivíduos tidos como membros da família é o uso popular mais antigo da fotografia.

\footnotetext{
Segundo um estudo sociológico feito na França, a maioria das casas em que há crianças tem uma probabilidade duas vezes maior de ter pelo menos uma câmera, em comparação com as casas sem crianças. Não tirar fotos dos filhos, sobretudo quando pequenos, é sinal de indiferença paterna, assim como não comparecer à foto de formatura é um gesto de rebeldia juvenil.
}

Para O’Donell, apesar de fotos de família, por serem privadas e espontâneas, parecerem muito fora do domínio e das principais preocupações dos arquivos, na verdade, a sua própria especificidade ajuda a desvendar um fato crucial: cada tipo de registro não só contém um histórico específico de informações e evidências sobre seus criadores, como também possui uma forma que revela algo único sobre a maior história das relações sociais estruturadas. É por isso que a autora defende que a proposta de "arquivos totais" dos canadenses, de documentar a história de toda a sociedade, deve ser baseada em uma abertura teórica e prática a todas as formas de registro. (O’DONNELL, 1994, p. 106).

A autora complementa sua leitura sobre os retratos de família definindo-os como parte de um sistema de práticas de representação, visuais e orais, que estão intimamente ligados com a forma como a família é construída. A família não é uma realidade objetiva estável, ela é um processo e sua história é realmente feita com e através da fotografia. Ou seja, a família não se 
limita a procurar uma certa forma nas fotos, mas é de certa forma por causa de fotografias que a família constrói-se em suas autorrepresentações. Esse é o reconhecimento epistemológico chave da teoria crítica cultural contemporânea: não podemos conhecer um assunto exceto por meio de suas representações.

\title{
3. A fotografia e suas possibilidades de definições
}

A fotografia não somente constitui um tipo de representação icônica que goza de um extenso uso cultural e uma ampla trajetória histórica como também apresenta uma morfologia específica e um tipo documental com características específicas. Ao longo das duas últimas décadas, surgiu um grande interesse no âmbito das ciências sociais e humanas em torno da fotografia, fato que tem possibilitado haver, em relação a esse meio documental, uma abordagem interdisciplinar e enfoques historiográficos, da história das técnicas fotográficas, filosóficos, artísticos, antropológicos, sociológicos, psicológicos, semióticos, educativos, para citar aqui apenas algumas.

No que tange ao conceito de imagem e à perspectiva icônica, adotaremos o conceito de Roman Gubern (apud PÉREZ, 1999, p. 206), que a define como:

\begin{abstract}
Una modalidad de la comunicación visual que representa de manera plásticosimbólica, sobre un suporte físico, un fragmento de entorno óptico (percepto), o reproduce una representación mental visualizable (ideoscena), o una combinación de ambos, y que es susceptible de conservarse en el espacio y/o en el tiempo para constituirse en experiencia vicarial óptica: es decir, en suporte de comunicación entre épocas, lugares y/o sujetos distintos de su existência, incluyendo entres estos últimos al propio autor da la representación en momentos distintos de su existencia.
\end{abstract}

Com referência às imagens, de acordo com Rouillé (2009, p. 37), são códigos que traduzem eventos em situações e processos em cenas, não porque eternizem eventos, mas porque substituem eventos por cena. Uma das novidades da fotografia foi, segundo o autor, a introdução da quantidade, do número e da medida na própria matéria imagem marcando o advento da série: uma passagem decisiva do único para o múltiplo, dos valores artísticos individuais para os valores industriais modernos.

Para Sontag, as fotos podem ser mais memoráveis do que imagens em movimento, porque são instantâneos do tempo e não um fluxo. A televisão, por exemplo, é um fluxo de imagens em que cada imagem subsequente cancela a precedente. Além disso, "uma foto equivale a uma prova incontestável de que determinada coisa aconteceu. A foto pode distorcer; 
mas sempre existe o pressuposto de que algo existe, ou existiu, e era semelhante ao que está na imagem (...)" (SONTAG, 2004, p. 16).

Ainda segundo a autora, a fotografia é uma forma de aquisição, e um exemplo é que, mediante máquinas que criam imagens e as duplicam, podemos adquirir algo como informação e não como experiência. Quando fotografamos algo, isso se torna parte de um sistema de informação adaptado a esquemas de classificação, desde o acúmulo de sequências cronológicas em álbuns de família até os sistemas mais avançados de acúmulos obstinados e o arquivamento meticuloso, necessário às mais diversas áreas (SONTAG, 2004, p. 172).

Nossa perspectiva aqui pretende enfocar a fotografia no ponto de vista informativodocumental, examinando a imagem como evidência de um registro dentro de um sistema da informação, estudando a gestão dos fundos e coleções fotográficas, e do tratamento de seu conteúdo de representação icônica para gerar representações documentais secundárias, visando possibilitar a recuperação dos documentos e das informações nelas contidas. Partindo dessa perspectiva, buscaremos a partir de agora a contribuição de autores que irão corroborar na construção teórica de nossa apresentação, no que diz respeito aos conceitos da fotografia e de suas características.

Não temos aqui a pretensão de fazer uma proposta epistemológica da fotografia, tão somente queremos promover os questionamentos das principais noções que compõem o tema, para recolocar a fotografia nas suas múltiplas possibilidades de estudo. É urgente a necessidade de, nas palavras de Rouille (2009, p. 17), “[...] traçar novas direções, experimentar novas ferramentas teóricas, a fim de evitar que a cultura fotográfica prospere sobre um imenso vácuo de ideias".

No que diz respeito ao conceito de fotografia, Lafuente (2013), na obra Tesauro y Diccionario de objetos asociados a la expresión artística, conceitua o termo como:

\footnotetext{
Instantánea conseguida mediante el proceso o arte de producir imágenes duraderas visibles, obtenidas directa o indirectamente por la acción de la luz u otra forma de energía sobre un soporte fotosensible: papel, placas o películas recubiertas previamente de sustancias sensibles a la misma. [...].
}

Para Cunha e Cavalcanti (2008, p.175), o termo fotografia é entendido como "técnica ou arte de produzir imagens visíveis pela ação da luz, que fixa essas imagens de modo direto e durável sobre uma superfície sensibilizada". Para Ejarque (2000, p. 217), é definido como "arte y técnica com las que fijar y reproducir por médio de reacciones químicas a la luz, sobre 
superfícies convenientemente preparadas, las imágenes visibles directa o indirectamente recogidas en el fondo de uma câmara oscura".

Para o Glossário proposto pela Câmara Técnica de Documentos Audiovisuais, Iconográficos e Sonoros - CTDAIS, do Conselho Nacional de Arquivos (CONARQ), o termo é definido como "imagem produzida pela ação da luz sobre película coberta por emulsão fotossensível, revelada e fixada por meio de reagentes químicos" (CONSELHO NACIONAL DE ARQUIVOS, 2014, p. 11).

Os conceitos aqui apresentados têm algo em comum, que é a ideia da captação da imagem pela ação da luz numa superfície coberta com substância sensível, apesar de haver um problema nas definições, que é o de excluir as fotos digitais, ou seja, produzidas pelas câmeras digitais. André Lopez (2000, p. 170) comenta a necessidade de ampliação desse conceito ao dizer que:

[...] o próprio conceito tradicional de imagem fotográfica é ampliado quando se considera não apenas o processo físico-químico de reação da luz por uma emulsão, mas também qualquer imagem obtida através de captura da luz (o que inclui imagens obtidas por câmeras digitais, porém exclui as montagens e as imagens digitais criadas pelo computador). [...] A diferença está na relação inicial com a cena retratada. $\mathrm{O}$ registro fotográfico feito pela câmera digital, mesmo não sendo analógico, é resultante da captura da luz emitida por um cenário real.

O autor inova o debate ao utilizar o termo documento imagético para designar as múltiplas possibilidades de ocorrência da imagem nos arquivos, para englobar as diversas categorias da imagem de modo mais amplo do que os termos fotografia, pintura, obras de arte etc. Mas, Lopez alerta que "nem todo registro fotográfico é necessariamente imagético: vejase, por exemplo, os registros fotográficos gerados para produzir os microfilmes de textos". (2000, p. 158).

Entendemos aqui, na proposta de Lopez, documento imagético como documento de arquivo e que os pesquisadores e profissionais da informação devem ter os cuidados necessários para não confundir análise documentária com a organização arquivística. No arquivo, o documento é entendido como testemunho de uma atividade e que seu objetivo principal é constituir provas das atividades de seu titular. $\mathrm{O}$ arquivo pode e deve disponibilizar informações para usuários em geral, todavia, como consequência direta de outro objetivo que é a difusão dos documentos pelo seu valor secundário, seja informativo, histórico ou cultural.

Apesar de reconhecermos aqui as valorosas contribuições das propostas de Lopez, não pretendemos destacar a rubrica de documentos fotográficos por considerá-lo necessário à 
identificação de nosso objeto de debate. Porém, ainda estamos buscando um diálogo entre a fotografia analógica e a digital, ambas como documento fotográfico, a partir do momento em que contêm uma informação registrada num suporte, não necessariamente um documento fotográfico de arquivo.

A colaboração de Franch (2008, p. 15) sobre o tema é muito interessante quando ressalta que o maior impacto da fotografia digital é o do "fenômeno da desmaterialização", que consiste na ausência de uma estrutura física da imagem, tendo consequências em todas as fases da intervenção, das quais a de conservação se torna a mais evidente. A questão da autenticidade, acesso, originalidade entre outros aspectos se tornam um desafio para os estudos sobre a questão, todavia, no nosso caso, estamos trabalhando com as fotografias digitalizadas, ou seja, capturada por um escâner com objetivo de preservar os originais e de potencializar o acesso, e não com fotos digitais.

Com a fotografia digital, o princípio da câmara escura permanece, porém, o processo químico desaparece, e isso produz uma verdadeira ruptura, já que o objeto final tem uma natureza bem diferente, distinguindo a era digital de suas precedentes. Além disso, poucos anos depois da aparição das primeiras câmeras digitais, na década de 1980, entraram em cena os editores de imagem e a World Wide Web, dois fatores determinantes do desenvolvimento e uso da fotografia digital. (FRANCH, 2008, p. 15).

Buscamos em Santaella (1998, p. 304) uma melhor delimitação do conceito do documento fotográfico utilizado nesse artigo. Para a autora, no processo evolutivo de produção de imagem existem três paradigmas.

O primeiro nomeia todas as imagens que são produzidas artesanalmente, ou seja, feitas à mão e que dependem fundamentalmente da habilidade de um individuo para construir o visível, a imaginação visual, que compreende desde a imagem nas pedras, o desenho, a pintura e a gravura, até a escultura, isto é, os processos artesanais da criação da imagem.

O segundo se refere àquelas imagens que mantêm uma conexão dinâmica e física com algo que existe no mundo e sua produção depende de máquinas que são capazes de registrar os objetos. Fazem parte desse paradigma fotografias, filmes, vídeos e também a holografia, em suma, os processos automáticos da captação da imagem.

O terceiro paradigma diz respeito às imagens sintéticas ou infográficas, inteiramente calculada por computação. Estas são o resultado da correspondência de uma matriz numérica 
com uma configuração de pixels elementares que podem ser visualizados na tela do computador. Este paradigma pós-fotográfico compreende as imagens derivadas de uma matriz numérica e produzidas por técnicas computacionais, enquanto no segundo paradigma predominam os processos automáticos de captação de imagem com o uso de equipamentos, em resumo, os processos automáticos de geração de imagem.

A infinidade de observações que permite este meio e por ele a infinidade de registros visuais de instantes fugazes, não observáveis de outra maneira, pode fazer emergir necessidades de apropriação e preservação. Como Barthes (1984, p. 13) diria, a imagem parece ser inclassificável, pois a fotografia "repete mecanicamente o que nunca mais poderá ser repetido existencialmente".

Vale dizer que consideramos a fotografia como um documento integrado por suporte e informação, transmissor de uma mensagem codificada que exige um esforço decodificador por parte do destinatário. Por isso, quando analisamos fotografias não analisamos a realidade, senão uma representação da realidade, se bem que é certo que se trata de uma representação muito fiel, em que pese aos códigos. Para Valle Gastaminza (1999, p. 114):

En el caso de la fotografía se trataría de estudiar la relación entre los diferentes procesos semióticos que dan entre los representámenes correspondientes a texto y foto referentes a un objeto dado frente a, al menos, tres interpretantes diferentes como son el fotógrafo, el documentalista y el usuario [...].

A imagem fotográfica exerce um importante papel na transmissão, conservação e visualização das atividades políticas, sociais, científicas ou culturais da humanidade, de tal maneira que se configura em verdadeiro documento social. O certo é que por meio da fotografia algo ou alguém situado num momento dado ante o objetivo de uma câmera passa a formar parte de um sistema de organização de conhecimento e informação, e pode ser armazenado e classificado em esquemas que vão, nas palavras de Susan Sontag (apud VALLE GASTAMINZA, 1999, p. 17):

\footnotetext{
Desde el orden toscamente cronológico de las series de instantáneas familiares hasta las tenaces acumulaciones y meticulosas catalogaciones necessárias para la utilización de la fotografia em predicciones meteorológicas, astronomia, microbiologia, geologia, investigaciones policiales, educación, diagnóstico médico, reconocimiento militar e historia del arte.
}

Para a estudiosa dos arquivos Heredia Herrera (1993), ao pensarmos no uso dos termos "arquivos fotográficos" e "fundos fotográficos" as entendemos como denominações que entram em conflito com a terminologia arquivística. No primeiro caso, a palavra arquivo é utilizada simplesmente para designar armazém de documentos, neste caso, fotográficos. De toda forma, 
o conceito de arquivo, no que se refere a fotografia, está somente associado com a dimensão de arquivos pessoais quando se trata de uma produção de um fotógrafo.

Ainda segundo a autora, tampouco o "fundo fotográfico" resulta de uma terminologia, na maioria das vezes, conveniente, porque um "fundo", para a arquivologia, tem uma relação de origem estreitamente ligada com uma instituição ou pessoa física e se identifica com todo o volume de sua produção documental, resultado de sua gestão e de suas atividades, quando, na maioria das vezes, podemos observar o termo sendo utilizado equivocadamente como sinônimo de coleção fotográfica que é do que realmente se trata em muito dos casos dos acervos encontrados nas instituições.

É indiscutível que a fotografia está presente na vida social, desde o álbum de família à internet, proporcionando documentos pensados como entretenimento, experimento científico, negócio, indústria etc., na intenção de mostrar a "realidade" dos fatos, de fazê-la visível através de uma representação um momento concreto. $\mathrm{O}$ estudo da fotografia, sua análise e tratamento clamam por um espaço específico como matéria especializada no amplo espectro da Ciência da Informação, da Arquivologia e de outras áreas, para estudar as suas distintas especialidades.

Para Schwartz (1995, p. 146), os arquivistas têm perpetuado o analfabetismo visual, promovendo uma concepção de fotografia, na maioria das vezes, descontextualizada, vista apenas em termos de seu valor informativo, acessível pelo nome ou lugar. Fotografias de arquivo são retiradas de seu contexto funcional e poder comunicativo e utilizadas por pesquisadores para "ilustrar" narrativas escritas, geralmente com o mínimo de informação de legenda. Por exemplo, fotografias horizontais são cortadas e reproduzidas como verticais para atender projeto de livro, e imagens são reproduzidas sem atribuição, o que reflete mais e reforça a ideia de que materiais visuais ocupam um nível mais baixo na hierarquia de documentos de arquivo.

Peter Burke (2004, p. 12), corrobora com a questão de que há um evidente analfabetismo visual na utilização das fontes fotográficas, no que diz respeito aos historiadores, ao dizer que nossa educação (aqui incluímos também o cientista da informação), tanto na escola quanto na universidade, foi um treinamento em ler textos.

[...] Quando utilizam imagens, os historiadores tendem a tratá-la como meras ilustrações, reproduzindo-as nos livros sem comentários. Nos casos em que as imagens são discutidas no texto, essa evidência é frequentemente utilizada para ilustrar conclusões a que o autor já havia chegado por outros meios, em vez de oferecer novas respostas ou suscitar novas questões. Por que isso acontece? Num ensaio em que descreve sua descoberta das fotografias Vitorianas, o falecido Raphael Samuel 
descreveu-se e a outros historiadores sociais de sua geração como "visualmente analfabetos".

Destacamos aqui a necessidade de aprofundarmos os princípios arquivísticos e suas formas de leitura e representação da fotografia para que o arquivista (e também o profissional da informação) possa alcançar um maior grau de alfabetização visual, e com isso ampliar a capacidade de "ler" a mensagem da fotografia, entender o seu valor de prova e compreendê-la como um documento de arquivo. Ao se buscar essa perspectiva será possível entender a fotografia como uma representação mediada da realidade, como produto de uma série de decisões, criado por uma vontade, para um propósito, para transmitir uma mensagem, para uma atividade.

\section{A fotografia como documento e objeto de análise}

Mas, como pensar a leitura da fotografia pelo profissional da informação diante da ambiguidade e o universo de possibilidades da fotografia? É primordial pensar a fotografia como objeto da análise documental da fotografia, pertencente a uma determinada coleção ou fundo, com o objetivo de obter uma representação de cada um deles, de forma que se possa, a partir de então, encontrar e recuperar o documento de acordo com critérios previstos e informar a seu respeito através de uma interface adequada.

Compreendemos aqui a leitura de imagem, nas palavras de Agustín Lacruz e Gimeno Arlamzón (2015, p. 102), como:

el examen y el desarrollo de un proceso de atribución de sentido cuyo propósito es explicar el contenido de la representación icónica y de su significado, con el propósito final de que se redacten los resúmenes documentales, los descriptores y las palabras clave, que permitan la recuperación de la información.

As imagens constituem uma modalidade de comunicação humana muito eficaz por sua riqueza expressiva e por sua universalidade semântica. A leitura de imagens é uma atividade complexa que requer conhecimentos, habilidades e estratégias conforme as diversas situações e a interação com outros sujeitos nos entornos sociais que envolvem os documentos fotográficos. Para Agustín Lacruz e Gimeno Arlanzón, no Diccionario Digital de nuevas formas de lectura y escritura, a leitura de imagem implica:

- la identificación de los diferentes códigos significativos que articulan los ámbitos en que se despliega el significado de la imagen;

- el conocimiento de los rasgos específicos del lenguaje visual y de su sistema de significación; 
- el conocimiento de la intencionalidad comunicativa y de los usos de la imagen;

- la capacidad para comprender y utilizar las imágenes con el fin de que el sujeto lector logre sus objetivos comunicativos. (LECTURA, 2013)

Para compreendermos o significado das imagens, temos que considerá-las como produtos sociais e históricos, e como tal evoluem tanto de forma diacrônica (ao longo do tempo) como sincrônica (no espaço). Na comunicação fotográfica, há intervenção, pelo menos, dos seguintes elementos básicos: o fotógrafo (autor, criador e/ou produtor da imagem); o receptor, ou seja, o leitor; a fotografia, isto é, a própria imagem icônica; e o contexto, o conjunto de elementos que situam o processo comunicativo.

Para analisar um documento é preciso conhecê-lo e isso implica colocar em prática diversas competências que levam à sua correta, ou supostamente correta, compreensão e interpretação. Para Valle Gastaminza (1999, p. 120), a leitura de imagens fotográficas está relacionada com a capacidade e atitudes do profissional da informação que compreende as seguintes competências: iconográfica, narrativa, estética e enciclopédica.

Com base em sua memória visual e cultural, o leitor identifica personagens e situações, contextos e conotações. Esta é provavelmente a mais importante competência para trabalhar com fotografias documentais. Pode ser uma competência basicamente enciclopédica, porém em muitos casos será uma habilidade especializada: é difícil trabalhar com fotografias da transformação urbana de uma cidade, se não se sabe reconhecer seus espaços, principais construções, comércios ou eventos. É preciso saber situar cada fotografia em seu contexto histórico.

- Competência linguístico-comunicativa. Com base nas suas competências linguísticas, o leitor atribui uma proposição à imagem da fotografia que poderá confrontar e coincidir ou não com a legenda da foto. Esta competência diz respeito ao trabalho do documentalista no sentido de que, em muitos casos, essa proposição passará a arquivarse com a fotografia.

- Competição Modal. O leitor interpreta espaço e tempo da fotografia e coloca adequadamente as coordenadas básicas do documento.

Essas competências certamente irão se confrontar com outras, como emotividade, memória visual, experiência e ideologia do leitor, cuja influência é significativa na interpretação da imagem. 
O objetivo principal do processo de análise documental é examinar a imagem como um registro ou evidência de interesse geral, como também buscar outros aspectos como os relativos às técnicas, qualidade estética, aspectos sociais, jurídicos etc., em consonância com outras disciplinas (AGUSTÍN LACRUZ, 2010, p. 88). Contudo, em se tratando de fotografia, devemos ser conscientes de que nunca um texto irá expressar com suficiência o que uma imagem transmite, nem dar conta da quantidade de informações que descreva os atributos contextuais de cada fotografia considerada como unidade documental.

Uma fotografia que surge totalmente descontextualizada e isolada de qualquer informação que consiga remontar sua gênese documental, talvez seja um dos maiores desafios a serem enfrentados no processo de ressignificação dos acervos fotográficos, hoje em poder das instituições custodiadoras.

Leite (2001, p. 31) alerta para os desafios nos acervos fotográficos dos tipos de imagem denominado como "fotografia anônima":

Trata-se de fotos tiradas rapidamente "com um mínimo de posses deliberadas da parte
do fotógrafo, no que se refere ao ponto de onde se tira, ao enquadramento e à
apreensão da imagem", derivadas, em parte, da mobilidade da câmera manual. Ao se
tornarem públicas, ou seja, quando esses instantâneos são arrancados de redes de
relações conhecidas e significativas, como quando estão conservadas em álbuns e
coleções de família, para enfrentar esquemas interpretativos os mais variados, ao
serem inseridas em coleções ou arquivos públicos, sofre alterações em suas
informações/desinformações primitivas.

Esse tipo de material caracteriza parte dos acervos encontrados nas instituições, formado desde fotografias de amadores ou de profissionais não identificados, até fotografias comerciais e de imprensa que se encontram totalmente fora do contexto em que foram produzidas e que foram organizados numa perspectiva que buscou minimamente dar um contexto a esse material, se não arquivístico pelo menos histórico e social.

A utilização da fotografia nos trâmites administrativos com fins oficiais se produz quase de maneira imediata à sua apresentação em Paris, no ano de 1839. Todavia, destacamos aqui a fotografia pessoal que retrata algo excepcional, relacionadas com o lazer e satisfação pessoal: nascimento e crescimento das crianças; férias e turismo; festas e cerimônias; e hobbies, como praticar esportes ou ter um animal de estimação. Normalmente, as fotografias de origem privada ingressam nos arquivos como fruto de uma política de recuperação do Patrimônio, que inclui a compra, doação ou depósito desse tipo de documento. 
Os acervos fotográficos oriundos de arquivos pessoais levam a grandes desafios para o profissional da informação no que diz respeito a sua organização e descrição. Enquanto numa instituição a sua organização está ligada a um processo de gestão documental e é possível relacioná-las a uma classificação e a atividades que a produziram, no âmbito privado essas fotografias encontram-se guardadas em caixa e pequenos álbuns sem qualquer identificação ou, nos dias atuais, armazenadas em CDs, HDs, ou álbuns virtuais na internet.

No Manual para la Gestión de Fondos y Colecciones Fotográficas, Boadas I Raset; Casellas; Suquet (2001, p. 121) aponta que os tipos de agrupamento desse material podem ser naturais e constituir um reflexo direto da maneira como se produziu e acumulou a documentação, ou podem ser artificiais, formados depois da produção da documentação em função das necessidades do produtor ou de alguém que já tenha dado uma ordenação ao conjunto. Ainda apresenta uma terceira possibilidade, que é quando a documentação, por motivo de traslado ou de uso descuidado, tenha se acumulado de maneira totalmente anárquica.

O manual orienta que o exame do conteúdo e a cronologia das fotografias sejam realizados por grupos de ordenação, que estejam a par das atividades do produtor, a fim de que empreguem as especialidades fotográficas que reflitam as atividades do produtor. Os autores definem as especialidades fotográficas como aquelas atividades realizadas pelos fotógrafos durante seu exercício profissional e que vão surgindo e consolidando-se a partir da evolução das técnicas fotográficas. "Algunas de las especialidades fotográficas más frecuentes son la fotografía científica, la fotografía de viaje, el retrato individual, la fotografía social, la fotografía publicitaria, la fotografía de moda, la fotografía artística, etc". (BOADAS I RASET; CASELLAS; SUQUET, 2001, p.122).

Para Boadas I Raset; Casellas; Suquet (2001, p.134), os diferentes estudos sobre a história da fotografia nos permite estabelecer quatro funções básicas a partir das quais surgem diversas especialidades ou atividades fotográficas. As funções básicas apontadas pelos autores são as seguintes: função de registro, função informativa, função publicitária e função artística. Os autores alertam que, em geral, essas funções não se dão de forma pura, isolada, senão que coexistam, ainda que se tenha o predomínio de uma delas em cada fotografia. A fotografia de registro, por exemplo, é também informativa e a fotografia informativa, muitas vezes, serve também para promover ideologias. A função artística não é exclusiva do quarto grupo, mas pode se dar nos três anteriores, especialmente nas fotografias de publicidade em que o sucesso desta depende, principalmente, da expressividade da sua imagem. 
Importante pensarmos na fotografia como função para entendermos o documento numa perspectiva arquivística. Cada foto é um momento único, convertido em um olhar que as pessoas podem guardar e olhar outras vezes. Fotos como a que esteve na primeira página de muitos jornais do mundo em 1972, quando uma criança sul-vietnamita nua, que acabara de ser atingida por uma bomba norte-americana, aparece correndo de braços abertos por uma estrada na direção da câmera e gritando de dor, contribuíram mais para aumentar o repúdio público contra a guerra do que as centenas de horas de barbaridade exibidas pela TV. Analisarmos o acervo fotográfico dentro da gênese documental pelo qual a mesma foi produzida é de suma importância para garantirmos seu contexto de produção para seus potenciais usuários.

\section{A fotografia e a questão da originalidade}

Passaremos agora a discutir um conceito de documento original, que é muito caro às questões relacionadas à fotografia. Para Lacerda (2008, p. 113), o termo "original", aplicado aos documentos fotográficos, é mais contextual e pode ser avaliado em cada situação documental específica em que um original é criado e, também, em cada caso específico no que concerne a arquivo. Levantamos essa questão neste momento pelo fato de uma imagem num negativo poder gerar inúmeras cópias, situação que vai de encontro ao estatuto do documento único e de sua autenticidade.

Segundo Walter Benjamin, num estudo a respeito da reprodutibilidade técnica da obra de arte, a reprodução tira da obra o que considera sua autenticidade. Para o autor, o aqui e agora compõem o conceito de sua autenticidade, "a totalidade do campo da autenticidade mantém-se alheia à reprodutibilidade - e, naturalmente, não somente a reprodutibilidade técnica" (BENJAMIN, 2013, p. 54). Para ele, a partir do momento em que é possível uma multiplicidade de revelações, tomando-se uma chapa fotográfica, a pergunta pela revelação autêntica não faz mais sentido.

Um original pode ter versões anteriores, as quais podem ser consideradas como originais distintos. Um discurso escrito pode ter passado por vários rascunhos, e uma cópia fotográfica pode ser feita a partir de um negativo. Em determinadas circunstâncias, as cópias são designadas como originais pela legislação, como é o caso no Brasil para a questão dos microfilmes que são legalmente considerados equivalentes ao original. Para a autora Luciana Duranti (1998, p. 165): 
An original is the first complete and effective document, that is, an original must present the qualities of primitiveness, completeness and effectiveness. With facsimile transmission, the first two qualities belong in the document transmitted while the latter belongs in the document received.

Ainda segundo Duranti (1996, p.33), no caso de fotografias, em primeiro lugar, há a imagem negativa, mas ela carece de perfeição (estado completo e capacidade para o trâmite), enquanto a primeira impressão que se extrai do negativo é o primeiro documento perfeito, isto é, o original. Se existirem muitos impressos desse mesmo negativo, nos deparamos com o caso de muitos originais do mesmo documento, ou seja, se houverem muitos impressos do mesmo negativo, a primeira impressão se realiza em subsequentes vezes e vai se distribuindo: a primeira é original, as outras são cópias como originais.

Nesse sentido, Lacerda (2008, p.113) corrobora com a questão ao argumentar que a questão da originalidade do documento fotográfico “(...) é mais contextual, circunstancial, de acordo com as características do acervo em questão, e pode ser avaliado em cada situação documental específica que cria um original”. Para Schwartz (1995, p. 46), o negativo pode ser de fato "o registro mais verdadeiro" porque não é o documento com a intenção de transmitir uma mensagem para o público. Segundo o autor, a Diplomática entende o negativo como apenas um esboço.

O fato de muitas impressões poderem ser feitas a partir de um único negativo ou que uma única impressão pode ser usada repetidamente em diferentes circunstâncias aponta para a possível existência de vários documentos fotográficos originais, com base na mesma imagem, mas feitos em vários momentos, para diversas finalidades e públicos diferentes. Esses conceitos demonstram que o significado de um documento fotográfico não está no conteúdo ou na forma, mas no contexto da criação de documentos.

Para Boadas I Raset; Casellas; Suquet (2001, p.258), no sentido estrito da palavra, o original da fotografia é o negativo fotográfico e a primeira cópia do autor, todavia, o conceito de cópia não pode ser aplicado da mesma maneira. Pode acontecer que o mesmo conteúdo icônico seja representado por métodos e formatos diferentes, feitos ao mesmo tempo ou em momentos diferentes, ou pode ser que isto tenha sido editado em séries diferentes pelo mesmo fotógrafo ou por diferentes profissionais. 
(...) Si se entiende que una copia es un documento que reproduce el contenido de un original obtenido por un medio técnico diferente, todos estos casos podrían considerarse copias. Pero a diferencia de los documentos textuales, éstos no son automáticamente eliminables. Todas las posibles versiones de una única imagen de un mismo autor nos muestran la utilización y la difusión de la fotografía en las diferentes épocas. Las representaciones de un mismo tema que hacen los distintos autores, señalan los tópicos que ha interesado representar en cada momento.

Em um comentário sobre essa questão, Schwartz (1995, p.51) observa que o valor informativo de uma fotografia é fixado pelo seu conteúdo e o seu valor probatório não é absoluto nem estático, pois varia de acordo com as várias circunstâncias de criação de documentos. Uma imagem fotográfica pode tornar-se vários documentos fotográficos separadamente; uma fotografia criada para uma finalidade poderá posteriormente ser utilizada para servir a outras.

Por exemplo, cada impressão idêntica pode ser feita em um momento diferente, para um fim diferente, e pode circular em diferentes discursos e finalidades - comerciais, científicas, políticas, econômicas, jornalísticas, sociais - e pode até servir a funções absolutamente opostas para a qual foi criada. Cada vez que um negativo é impresso, cada vez que uma cópia é usada, a imagem fotográfica é transformada num documento fotográfico criado por um autor com a finalidade de transmitir uma mensagem a uma função diferente da sua gênese documental.

Não importa quantas cópias existam de um determinado documento, num mesmo arquivo ou em arquivos distintos. Em cada caso, devido ao significado que lhe for atribuído pelo produtor daquele arquivo, o documento/cópia será arquivado de forma distinta seguindo a característica da naturalidade e organicidade e, dessa forma, cada um será único em seu contexto. (OLIVEIRA, 2012, p. 67).

Cada utilização deve ser entendida como distinta, embora às vezes inter-relacionadas. Por esta razão, a existência da fotografia idêntica, em duas ou diferentes instituições, não deve ser interpretada como a duplicação, mas deve ser entendida como o resultado lógico de apropriação e reapropriação de uma fotografia com conteúdo e a configuração física em diferentes contextos funcionais, com a transformação de uma única imagem em documentos múltiplos.

Rondinelli (2013, p.184) aborda a importância da Diplomática na conferência da autenticidade dos documentos destacando que esta considera "autênticos os documentos elaborados de acordo com as práticas de seu tempo e devidamente atestados por quem de direito". Hilary Jenkinson contribui com uma dimensão bastante interessante ao relacionar a autenticidade à custódia permanente dos arquivos por seu produtor ou sucessor legítimo. Tratase do conceito da linha idônea de custodiadores responsáveis, segundo o qual a qualidade da 
autenticidade nos arquivos depende da capacidade de se manter uma cadeia ininterrupta de custódia.

Cabe destacarmos aqui que autenticidade sozinha não implica automaticamente que o conteúdo de um registro é confiável. Enquanto a autenticidade compreende a credibilidade de um documento na sua qualidade de ser o que diz ser e de que está isento de adulteração ou qualquer outro tipo de modificação indevida, a confiabilidade compreende a credibilidade de um documento arquivístico enquanto afirmação de um fato estabelecido pelo exame da completeza, da forma do documento e do grau de controle exercido no seu processo de criação. (CONSELHO NACIONAL DE ARQUIVOS, 2011, p. 126).

\section{Considerações finais}

A fotografia como documento de arquivo deve ser pensada como tal. Para isso, as sete atividades da arquivística - produção, avaliação, aquisição, conservação, classificação, descrição e difusão - devem ser pensadas dentro do contexto dos documentos fotográficos inseridos nos arquivos e suas mais diversas possibilidades. Além disso, é necessário pensarmos na aproximação com outras disciplinas e temáticas, como diplomática, preservação digital, vocabulário controlado, mediação e, principalmente, da questão do estudo da fotografia e seu crescimento crescente nas redes digitais e na internet.

Nessa perspectiva, é importante considerar as possibilidades que a Diplomática oferece ao nos trazer orientação pela qual podemos reconsiderar a fotografia no processo através das suas noções refinadas do que constitui a autoridade, a autenticidade, o propósito, e os elementos extrínsecos e intrínsecos da fotografia pensada como documento de arquivo. É preciso que pensemos que todos os acervos, inclusive o fotográfico, configuram-se a partir da produção documental, que só pode ser entendido como conjunto a partir de atividades que o transformaram num todo, constituindo um corpus documental.

Nesse contexto, devemos repensar a natureza, produção e o propósito de fotografias como documentos, a fim de alcançar uma compreensão contextual do seu uso no âmbito dos governos, dos negócios e dos indivíduos para transmitir a política do governo, comunicar ideologia corporativa, construir identidade nacional, a forma de memória coletiva, estabelecer espaço simbólico e definir conceitos de si e a premissa cultural do outro. Estamos trabalhando com a ideia de que fotografias são documentos, criados por uma vontade, para um propósito, 
para transmitir uma mensagem de uma determinada atividade. Para entendê-los como produto de ações e transações, seja burocrática ou sociocultural, temos de devolvê-los para a ação de que participaram. É seu contexto funcional que transforma imagens fotográficas em documentos de arquivo. (SCHWARTZ, 1995, p. 41).

Concordamos com Tognoli e Guimarães (2011, p. 42), para quem o maior desafio em abordar o tema é garantir a organização do conhecimento arquivístico (no nosso caso, dos acervos fotográficos) e a sustentação da disciplina em um momento de rupturas paradigmáticas e inovações tecnológicas. A partir do reconhecimento do valor documental da fotografia, se faz necessário que determinemos as suas características como parte dos acervos arquivísticos e nos empenhemos na tarefa de apontar suas principais características dentro do processo de descrição e de leitura de imagens.

Quando nos referimos ao tratamento documental, entendemos que as funções arquivísticas de produção, avaliação, aquisição, conservação, classificação, descrição e difusão somente ocorrem com os documentos de arquivo, mesmo assim, precisamos ter em mente, apesar das diferenças entre coleções e arquivos, que ambos convivem dentro de um espaço institucional e precisam ser pensados como parte de um patrimônio documental. Mesmo no caso de arquivos, é muito raro pensarmos num agrupamento documental intacto que consiga abarcar todo o material de uma determinada atividade, instituição ou indivíduo.

Buscamos nesta breve apresentação elencar a problemática da fotografia dentro do âmbito do arquivo e conceituar os documentos fotográficos dentro de um estado de coisas. Uma vez reconhecida a fotografia como documento de arquivo, é necessário estudos e reflexões sobre as atividades de arquivo como a avaliação, a classificação e a descrição arquivística, bem como a sua aplicabilidade na fotografia como objeto de análise documental, seus métodos e possibilidades de leituras de imagens. 


\section{Referências}

AGUSTÍN LACRUZ, M. C.; GIMENO ARLANZÓN, B. La lectura de las imágenes fotográficas orientada hacia la representación documental. Encontros Bibli: Revista Eletrônica de Biblioteconomia e Ciência da informação, Florianópolis, v. 20, n. esp., p. 5588 , jan. 2015.

El contenido de las imágenes y su análisis en entornos documentales. In: GÓMEZ DÍAZ, R.; AGUSTÍN LACRUZ, M. C. (Eds.), Polisemias visuales: aproximaciones a la alfabetización visual en la sociedad intercultural. Salamanca: Ediciones Universidad de Salamanca, 2010. p. 85-116.

BARTHES, R. A câmara clara: nota sobre a fotografia. Rio de Janeiro: Nova Fronteira, 1984.

BENÍTEZ, A. S.; RODRIGUES, A. A. R. Archivos fotográficos: pautas para su integración em el entorno digital. Granada: Editorial Universidad de Granada, 2006.

BENJAMIN, W. A obra de arte na era de sua reprodutibilidade técnica Porto Alegre: L\&PM, 2013.

BOADAS I RASET, J.; CASELLAS, L.; SUQUET, M. Manual para la gestión de fondos y colecciones fotográficas. Girona: Biblioteca de la Imagen, CCG Ediciones - Ajuntament de Girona (CRDI), 2001.

BURKE, P. Testemunha ocular: história e imagens. São Paulo: EDUSC, 2004.

CAZES, L. Dignidade eternizada em um retrato. O Globo, Rio de Janeiro, 7 jul. 2013. Caderno Prosa, p. 6.

CONSELHO NACIONAL DE ARQUIVOS (CONARQ). Câmara Técnica de Documentos Eletrônicos. e-ARQ Brasil: modelo de requisitos para sistemas informatizados de gestão arquivística de documentos / Câmara Técnica de Documentos Eletrônicos. 1.1. versão. Rio de Janeiro: Arquivo Nacional, 2011.

sonoros. 2014.

Glossário da câmara técnica de documentos audiovisuais, iconográficos e

CUNHA, M. B.; CAVALCANTI, C. R. O. Dicionário de Biblioteconomia e Arquivologia. Brasília: Briquet de Lemos, 2008.

DURANTI, L. Diplomatics: new uses for an old science. society of american archivists and Association of Canadian Archivists in association with Scarecrow Press, 1998.

Diplomática: usos nuevos para una antigua ciencia. Carmona: S\&C, 1996.

EJARQUE, L. G. Diccionario del archivero-bibliotecário: terminologia de la elaboración, tratamento y utilización de los materiales propios de los centros documentales. Gijón: Trea, 2000 . 
FRANCH, D. I. La fotografia digital em los archivos: que és y como se trata. Gijón: Trea, 2008.

HEREDIA HERRERA, A. La fotografía y los archivos. In: FORO IBEROAMERICANO DE LA RÁBIDA. Jornadas Archivísticas, 2., 1993, Palos de la Frontera. La fotografia como fuente de información. Huelva: Diputación Provincial, 1993.

LACERDA, A. L. A fotografia nos arquivos: um estudo sobre a produção institucional de documentos fotográficos das atividades da Fundação Rockefeller no Brasil no combate à febre amarela. Tese (Doutorado) - Faculdade de Filosofia, Letras e Ciências Humanas, Universidade de São Paulo, São Paulo. 2008.

LAFUENTE, I. T. Tesauro y diccionario de objetos asociados a la expresión artística: tesauro y diccionario para la descripción y catalogación de bienes culturales. Madrid: Ministerio de Educación Cultura y Deporte, 2013.

LECTURA de imágenes. In: AGUSTÍN LACRUZ, M. C.; GIMENO ARLANZÓN, B. Diccionario digital de nuevas formas de lectura y escritura. Salamanca: Universidad de Salamanca, 2013. Red Internacional de Universidades Lectoras. Disponível em: <http://dinle.eusal.es/searchword.php?valor=Lectura de imágenes>. Acesso em: 12 mar. 2015.

LEITE, M. M. Retratos de família. 3.ed. São Paulo: Edusp, 2001.

LOPEZ, A. P. A. As razões e os sentidos: finalidades da produção documental e interpretação de conteúdos na organização arquivística de documentos imagéticos. Tese (Doutorado em História Social) - Programa de Pós-Graduação em História Social da FFLCHUSP, São Paulo, 2000.

O'DONNELL, L. Towards total archives: the form and the meaning of photographic records. Archivaria. The Jornal of the Association of Canadian Archivist, n. 38, p. 105-118, Fall 1994.

OLIVEIRA, L. M. V. Descrição e pesquisa: reflexões em torno dos arquivos pessoais. Rio de Janeiro: Móbile, 2012.

PÉREZ, A. H. La fotografia digital. In: GASTAMINZA, F. V. Manual de documentación fotográfica. Madrid: Síntesis, 1999.

RONDINELLI, R. C. O documento arquivístico ante a realidade digital: uma revisitação conceitual necessária. Rio de Janeiro: FGV, 2013.

ROUILLÉ, A. A fotografia entre documento e arte contemporânea. São Paulo: SENAC, 2009.

SANTAELLA, L. Os três paradigmas da imagem. In: SAMAIN, E. O fotográfico. São Paulo: Hucitec, 1998.

SCHWARTZ, J. M. We make our tools and our tools make us: lessons from photographs for the practice, politics, and poetics of diplomatics. Archivaria: The journal of the Association of canadian Archivist, n. 40, p. 40-74, Fall 1995. 
Records of simple truth and precision: photography, archives, and the illusion of control. Archivaria, v. 50, p. 1-50, 2000.

SONTAG, S. Sobre fotografia. São Paulo: Companhia das Letras, 2004.

TOGNOLI, N. B. T.; GUIMARÃES, J. A. C. A organização do conhecimento arquivístico: perspectivas de renovação a partir das abordagens científicas canadenses. Perspectivas em Ciência da Informação, v.16, n. 1, p.21-44, jan./mar. 2011.

VALLE GASTAMINZA, F. El análisis documental de la fotografía. In: Manual de documentación fotográfica. Madrid: Síntesis, 1999. 